\title{
The behaviour of consolidated volcanic tuffs: weathering mechanisms under simulated laboratory conditions
}

\author{
H. Stück · L. Z. Forgó · J. Rüdrich • \\ S. Siegesmund · Á. Török
}

Received: 10 April 2008/Accepted: 10 April 2008/Published online: 3 June 2008

(C) The Author(s) 2008

\begin{abstract}
Five volcanic tuffs ranging from dacitic tuffs of Hungary to rhyolite, phonolite and basaltic tuffs of Germany were consolidated under laboratory conditions. Prior to consolidation an anti-hygro, a hydrous consolidant, which reduces the swelling ability of clay minerals, was applied. The three consolidants, a silicic acid ester (SAE), an elastic silicic acid ester (eSAE) and an acrylate resin (PMMA) were applied on test specimens under vacuum. Petrographic characterisation (polarizing microscopy, XRD, SEM) provided data for fabric analyses and the mineral composition of the tuffs. Changes in fabric, effective porosity, density, tensile strength, ultrasonic wave velocity were evaluated after the treatment. Weathering simulation tests such as hygric dilatation and thermal dilatation aimed to prove the effectiveness of consolidation and the durability of consolidated tuff samples. More than 500 samples were analysed. The tests showed that SAE caused the highest increase in indirect tensile strength. The water absorption and the pore size distribution of the tuffs were modified by consolidation. The PMMA reduced the water absorption the most, whereas SAE modified it the least. All the tested consolidants increased the thermal dilatation of the tuffs. The changes in hygric dilatation
\end{abstract}

H. Stück $(\square) \cdot$ J. Rüdrich · S. Siegesmund Geoscience Centre of the University of Göttingen, Goldschmidtstrasse 3, 37077 Göttingen, Germany e-mail: heidrun.stueck@gmx.de

S. Siegesmund

e-mail: ssieges@gwdg.de

L. Z. Forgó · Á. Török

Department of Construction,

Budapest University of Technology and Economics,

1111 Budapest, Stoczek u. 2, Budapest, Hungary

e-mail: torokakos@mail.bme.hu were not uniform: for most tuffs SAE increased and PMMA decreased the hygric dilatation, although the clayrich Habichtswald tuff showed the opposite trend. The changes in hygric and thermal behaviour of consolidated tuff require special care when specific consolidants are chosen. These products modify the physical properties of consolidated tuffs and change the behaviour of weathering.

Keywords Strengthening agents - Tuff .

Silicic acid ester · PMMA · Durability

\section{Introduction}

Stone conservation is one of the key issues in preserving our cultural heritage. Various consolidants are used when serious weathered stones are found. The consolidants are applied to strengthen the loosened stone surfaces and to slowdown the disintegration processes. The proper choice of consolidant is essential, because consolidation is an irreversible intervention. The properties of the stone are modified by consolidation, and this might significantly influence the behaviour of the stone. Various stone consolidants and water repellents are known from organic products to silicic acid esters. In this study, two types of silicic acid esters and a polymethyl methacrylate were tested. Sandstones and volcanic tuffs are the most appropriate stone materials for evaluating the effectiveness of silica-based stone consolidants (Weber 1983).

Volcanic tuffs were the favoured building materials for many people throughout human history, such as the people, who built the giant statues on Easter Island, or throughout the Roman culture and Medieval Europe. The easy workability of volcanic tuffs makes them a highly valued building material. However, this property also implies a 
lower resistance to weathering (Egloffstein 1998; Fitzner 1994). Thermal and hygric dilatation as well as ice crystallisation inside pore spaces are the responsible processes involved in the weathering of porous tuffs (Steindlberger 2004; Ruedrich et al. 2005). Their sensitivity to weathering is often related to the high clay mineral content. In order to circumvent the damages caused by swelling clays, swelling inhibitors could be applied before the consolidation.

Even though a large database on stone consolidants exists today, the selection of a consolidant for a particular stone is based on empirical experience. It is important to address the compatibility between the stone and the consolidant in question.

Only a few investigations have dealt with the compatibility between consolidants and the weathering mechanisms of volcanic tuffs. The exceptions include the study of German tuffs (Egloffstein et al. 1996; Hilbert 1999; Wendler 2001; Forgó et al. 2006) and the tuffs of Easter Island (Lazzarini et al. 1996).

Five tuffs were treated with three different consolidants to characterise the influence of these stone preservation agents. Prior to consolidation a product that reduces the swelling ability of clays was used. Detailed petrographic analyses were done on all the volcanic tuffs. Investigations sensitive to weathering processes were conducted, which included porosity, pore-radii distribution, capillary water uptake, moisture absorption, tensile strength and ultrasonic wave velocity measurements. The goal of the study was to characterise the effect of consolidants on the durability of tuffs. The consolidated samples were subjected to weathering simulations such as thermal and hygric dilatation as well as ice crystallisation.

\section{Materials}

\section{Stones}

Five volcanic tuffs were tested under laboratory conditions. Three tuffs from Germany ranging from basaltic to rhyolite

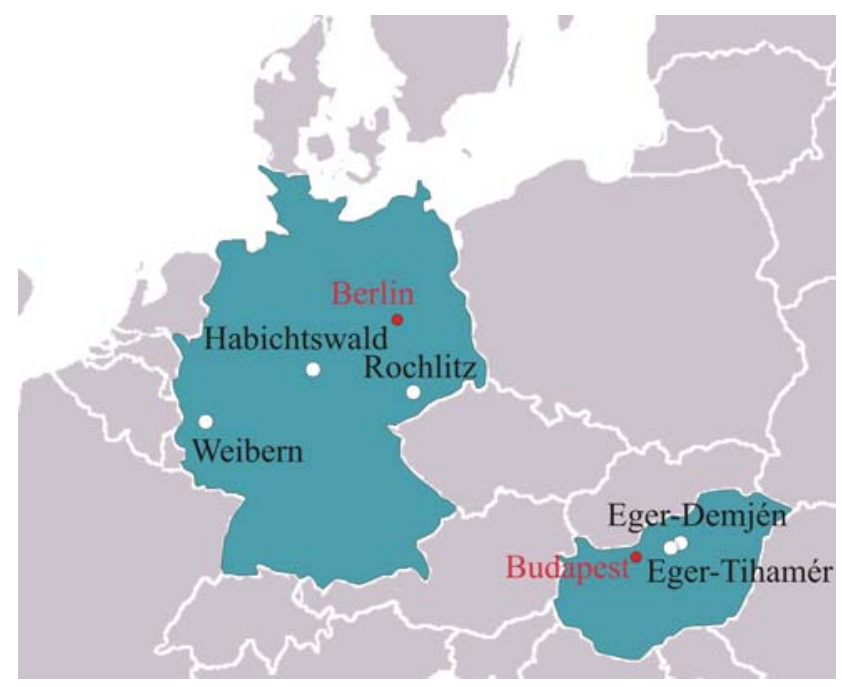

Fig. 1 Location of the German and Hungarian quarries from where the studied tuffs were collected

tuff and two acid volcanic tuffs from Hungary (Eger region) were used for the tests. The localities from where the tuffs were collected are shown in Fig. 1 and the most important properties are listed in Table 1.

Macroscopic observation of the phonolitic tuff from Weibern (WE) shows a characteristic yellowish grey, finegrained matrix, a weakly pronounced bedding as well as rock fragments ranging in size up to $10 \mathrm{~mm}$. The lithic clasts have a different shape and colour (Fig. 2a). In thin section (Fig. 2b) the Weibern tuff exhibits a porphyritichyalopilitic fabric. It is characterised by nearly $12 \%$ lithic clasts that are embedded in a very fine-grained matrix of zeolite minerals. The lithic clasts are almost exclusively of sedimentary origin, like quartz sandstones and shale fragments. Pumice lapilli (12 $\mathrm{mm}$ in diameter) and basaltic rock fragments also occur. The latter ones are characterised by pyroxenes and olivines. Rare leucite clasts and phenocrysts of nepheline, hornblende, augite, plagioclase and biotite are also visible.

Table 1 Characteristics of the volcanic tuffs investigated in the study

\begin{tabular}{|c|c|c|c|c|c|}
\hline $\begin{array}{l}\text { Locality/name } \\
\text { (country) }\end{array}$ & $\begin{array}{l}\text { Symbols used } \\
\text { in the text }\end{array}$ & Lithology & Age & Colour & Main components \\
\hline Weibern (G) & WE & Phonolite tuff & Quaternary & Yellowish-grey & Sedimentary rock and basalt fragments in a zeolitic matrix \\
\hline Habichtswald (G) & HA & Basalt tuff & Miocene & Greenish-grey & Pyroclasts $(-30 \mathrm{~mm})$ in a smectite-zeolite matrix \\
\hline Rochlitz (G) & RO & Rhyolite tuff & Permian & Red & $\begin{array}{l}\text { Elongated glass fragments, quartz, feldspars in a fine- } \\
\text { grained matrix with dispersed hematite }\end{array}$ \\
\hline Eger-Demjén $(\mathrm{H})$ & ED & Dacite tuff & Miocene & Light grey & $\begin{array}{l}\text { Lithic clasts of pumice, } \mathrm{k} \text {-feldspar, biotite, amphibole } \\
\text { crystals in a partly hyalopilitic matrix }\end{array}$ \\
\hline Eger-Tihamér $(\mathrm{H})$ & ET & Dacite tuff & Miocene & Light grey & $\begin{array}{l}\text { K-feldspar, quartz, biotite, pumice clasts in a } \\
\text { microcrystalline matrix }\end{array}$ \\
\hline
\end{tabular}

$G$ Germany; $H$ Hungary 
Fig. 2 Macroscopic and microscopic fabric images of the various volcanic tuffs in the study. a, b WE tuff: greenish grey phonolite tuff; c, d HA tuff: greenish-grey basaltic tuff; $\mathbf{e}, \mathbf{f}$ RO tuff: red ryolite tuff; $\mathbf{g}, \mathbf{h}$ ED tuff: light grey dacite tuff; $\mathbf{i}$, j ET tuff: light grey dacite tuff
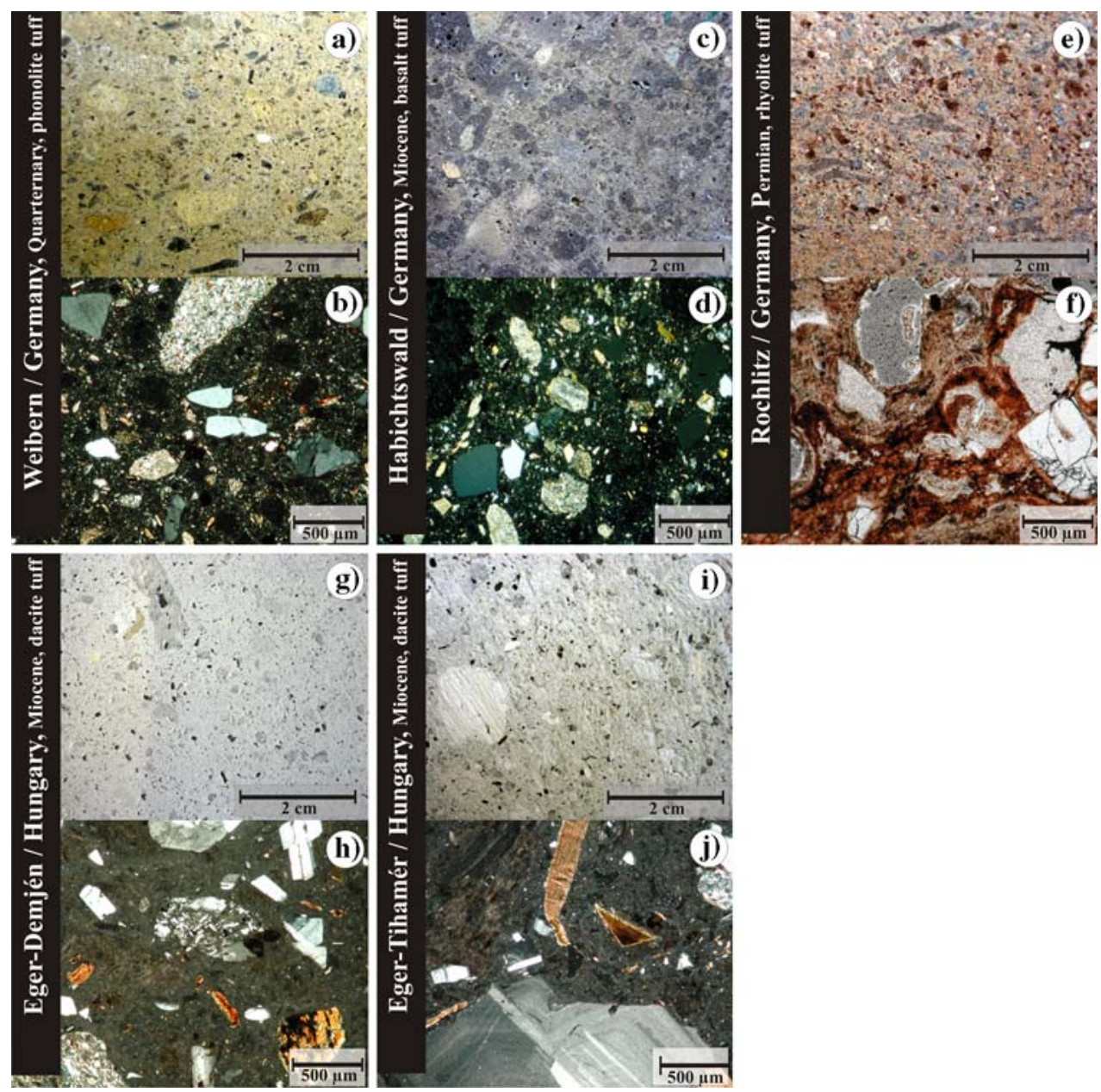

The basaltic lapilli tuff of Habichtswald (HA) is characterised by lithic clasts with a grain size of $0.5-30 \mathrm{~mm}$ in diameter (Fig. 2c). These are embedded in a greenish dark grey, fine-grained matrix, which consists of smectite and zeolite. These minerals represent alteration products from the original vitreous ash particles. In thin section the lapilli tuff from Habichtswald shows a hyalopilitic fabric. Olivine, augite, clinopyroxene and plagioclase crystals are recognisable in the vitreous matrix (Fig. 2d). Hornblende, biotite and magnetite are less common. The lithic clasts are dominated by black microcrystalline vitreous fragments and greenish-yellow peridotite clasts up to $2 \mathrm{~cm}$ in diameter as well as basaltic clasts consisting of plagioclase, olivine and pyroxene.

The rhyolite tuff from Rochlitz (RO) displays elongated glass fragments (up to $10 \mathrm{~mm}$ in length), which are suggestive of bedding or a flow fabric (Fig. 2e). The typical red colour of the stone is the result of finely dispersed hematite. Quartz and reddish feldspar form the main components of the fine-grained matrix. The quartz crystals are nearly idiomorphic and have resorptive structures (Fig. 2f). The feldspars are often entirely transformed to sericite. Additionally, intensively altered mica as well as opaque minerals such as magnetite appear. All the grains are surrounded by the reddish, fine-grained hematite. The glass particles are similar to fluid structures in a welded ignimbrite.

The light grey, compact, durable dacite ignimbritic tuff of Eger-Demjén (ED) has a microcrystalline porphyritic fabric (Fig. $2 \mathrm{~g}$ ). It is characterised by up to $15 \mathrm{~mm}$-sized clasts in a fine-grained, partially hyaline matrix. Pumice clasts, which are sometimes oriented and elongated, are found in the fine glassy matrix with sizes up to $20 \mathrm{~mm}$. Additionally, clasts (10 mm in size) consisting of pyroxenes and feldspars can also be observed. The main minerals are idiomorphic sanidines (up to $15 \mathrm{~mm}$ ) as well as biotite and amphiboles (Fig. 2h). The sanidine crystals often show multiple intergrowths and twins. The biotite crystals are partially altered to chlorite, which is due to hydrothermal processes.

The light grey, very porous dacitic ignimbrite of the Eger-Tihamér quarry (ET) has a microcrystalline porphyritic fabric (Fig. 2i). In composition it is very similar to the ED tuff described earlier. The very fine-grained matrix of 
this tuff is characterised by white, threaded pumice clasts of different shapes and sizes (up to $6 \mathrm{~cm}$ ). The pumice clasts can also exhibit a yellowish colour. Feldspar, quartz and biotite are the main phenocrysts. It is rich in biotite with sizes up to $2 \mathrm{~mm}$. Idiomorphic and hypidiomorphic quartz crystals show similar grain sizes. The sanidine crystals are characterised by multiple intergrowths and twins. The maximum observed grain size is $25 \mathrm{~mm}$ (Fig. 2j).

\section{Weathering forms}

The main weathering phenomenon occurring on these Hungarian and German volcanic tuffs are flaking (often also multiple flaking, Fig. 3a), scaling (Fig. 3d) and relief due to selective weathering (Fig. 3e). However, it is mentioned that salt weathering also damages the tuff texture. The deterioration is caused by the alkaline and earth alkaline ions of the zeolites, in zeolitic tuffs (Egloffstein et al. 1996). Common weathering forms are crusts (Fig. 3c), biogenic colonisation (Fig. 3a), colour change, crumbling, cracking, fissures and pollution (Török et al. 2004, 2007; Steindlberger 2002; Egloffstein 1998). These weathering features can occur with different intensities and can overlap on the stone surfaces.

\section{Products}

The most typical forms of weathering at volcanic tuffs like scaling and flaking (Egloffstein 1998; Egloffstein et al. 1996; Steindlberger 2002; Török et al. 2007) are especially severe when clay minerals are present. This is partly due to the swelling ability of clay minerals (Egloffstein 1998; Auras et al. 2000; Steindlberger 2004; Auras and Steindlberger 2005). To minimise the hygroscopic swelling of clays, an agent with bifunctional alkylammonium

Fig. 3 Main weathering forms of Hungarian and German volcanic tuffs, like a (multiple) scaling and coeval biogenic colonisation, b flaking, $\mathbf{c}$ thick crust, $\mathbf{d}$ flaking and scaling in combination, e weathering out of components and $\mathbf{f}$ flaking thin crust
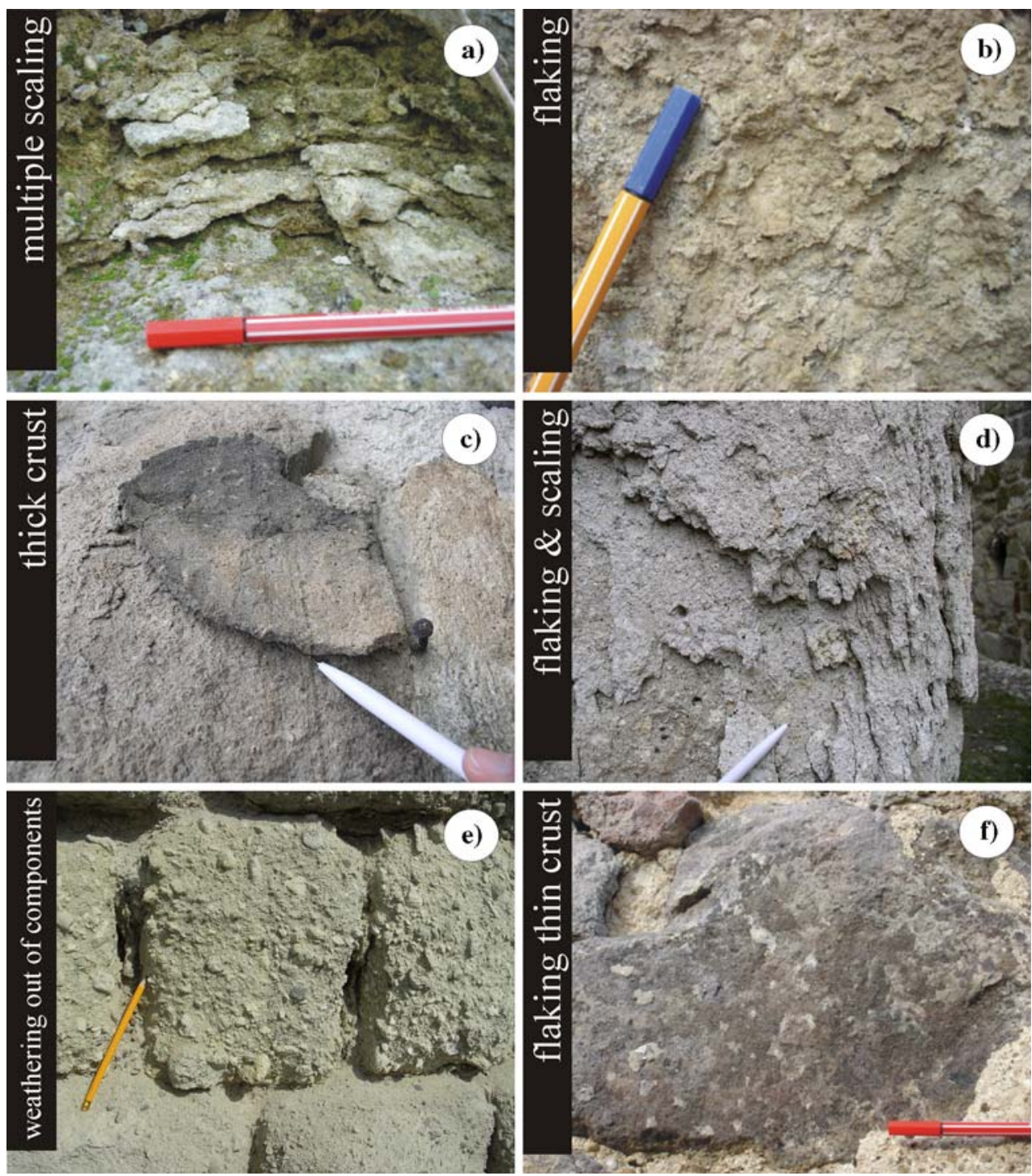
Table 2 Technical data of the consolidants used in the study

\begin{tabular}{|c|c|c|c|c|}
\hline Symbol & $\mathrm{AH}$ & SAE & eSAE & PMMA \\
\hline Full name & Anti-hygro & Silicic acid ester & Elastic silicic acid ester & Polymethyl methacrylate \\
\hline Effective substance & $\begin{array}{l}0.2 \mathrm{~mol} / \mathrm{l} \text { tenside } \\
\text { (butyldiammoniumcloride) }\end{array}$ & $\begin{array}{l}75 \mathrm{~m} \% \text { ortho-silicic acid } \\
\text { ester }\end{array}$ & $\begin{array}{l}\sim 40 \mathrm{~m} \% \text { ortho-silicic acid } \\
\text { ester }\end{array}$ & $\begin{array}{l}25 \% \text { polymethyl } \\
\text { methacrylate }\end{array}$ \\
\hline Solvent & Water & $25 \mathrm{~m} \%$ ethanol & $\sim 60 \mathrm{~m} \%$ ethanol & $75 \%$ xylol \\
\hline Density & $1 \mathrm{~g} / \mathrm{cm}^{3}\left(20^{\circ} \mathrm{C}\right)$ & $0.94 \mathrm{~g} / \mathrm{cm}^{3}$ & $0.92 \mathrm{~g} / \mathrm{cm}^{3}\left(20^{\circ} \mathrm{C}\right)$ & $0.95 \mathrm{~g} / \mathrm{cm}^{3}\left(20^{\circ} \mathrm{C}\right)$ \\
\hline Colour & Clear & Clear or yellowish & Clear or yellowish & Yellowish \\
\hline Catalyst (pH) & $6+1$ & Neutral & Neutral & NA \\
\hline Molecule size & NA & $\begin{array}{l}1.2-6 \mathrm{~nm} \text { (average: } \\
3 \mathrm{~nm})\end{array}$ & $1.2-6 \mathrm{~nm}$ & $24 \mathrm{~nm}$ \\
\hline $\begin{array}{l}\text { Harmful by- } \\
\text { products }\end{array}$ & No & No & No & NA \\
\hline Drying time & 2 weeks & $2-3$ weeks & 3 weeks & NA \\
\hline Comments & Swelling decreaser & $\begin{array}{l}\text { One component non- } \\
\text { hydrophobic }\end{array}$ & $\begin{array}{l}\text { One component non- } \\
\text { hydrophobic elastic }\end{array}$ & $\begin{array}{l}\text { Two component effective } \\
\text { substance: } \sim 5 \%\end{array}$ \\
\hline
\end{tabular}

molecules was developed that has a minor influence on the strength, water uptake and diffusion behaviour of the treated stone (Hilbert 1999). In this study, the anti-hygro agent was used for a pre-treatment of the tuffs before consolidation was implemented (Table 2).

Silicic acid ester (SAE) agents have been used in the conservation of stones for more than 30 years (Boos 2004). Their utilisation is advocated principally for silica-based stone materials like sandstone or volcanic tuff. However, their effectiveness is mostly restricted to stones, where larger macropores, microcracks or loose areas under crusts are found (Hilbert 1999). The SAE $\left(\mathrm{Si}\left(\mathrm{OC}_{2} \mathrm{H}_{5}\right)_{4}\right)$ contains a monomeric $\left(\mathrm{Si}(\mathrm{OR})_{4}\right)$ and oligomeric $\left(\left[\mathrm{SiO}(\mathrm{OR})_{2}\right]_{\mathrm{n}}\right)$ silicic acid molecules, organic ethyl-alcohol $\left(\mathrm{CH}_{3} \mathrm{CH}_{2} \mathrm{OH}\right)$ and inorganic silicic acid $\left(\mathrm{Si}(\mathrm{OH})_{4}\right)$ components. The threedimensional silicic gel builds up in several steps, due to hydrolysis, condensation and polymerisation processes. It is chemically bonded with the silanol groups of the mineral surfaces (see quartz) in the pores (Utz 2004). Table 2 lists the properties of the agents. The silicic gel forms plates of about $10 \mu \mathrm{m}$ in thickness. During the strengthening, the silicic gel might show characteristic shrinking fissures. The secondary porosity of the silicic gel structure ensures the "breathing" of the stone and provides permeability for water vapour (Boos 2004). Silicic acid ester conserving agents have been used on the Moai sculptures of Easter Island (Lazzarini et al. 1996), or in Dresden at the Zwinger Palace, on the famous Cologne Cathedral (von PlehweLeisen et al. 2004) and at Stephan's Cathedral in Vienna (Hilbert 1999). The consolidant was also used to treat the Loggia Cornaro in Padua (Fassina et al. 2004), the Brandenburg Gate and the Kaiser-Wilhelm Memorial Church in Berlin (Weber 1993).

Elastic silicic acid ester (eSAE) agents were developed in Germany in 1995 (Boos et al. 1996; Grobe et al. 2001;
Wendler 2001). Larger gel plates are formed when using the eSAE in contrast with the SAE. This substance can be used for bridging up to thicknesses of $300 \mu \mathrm{m}$, especially in slackened zones with microcracks, or can fill larger pore spaces and bind coarser grains. The eSAE differs from the $\mathrm{SAE}$ by having molecules with polyether elastic bridges $\left(\left[\mathrm{O}\left(\mathrm{CH}_{2}\right)_{2}\right]_{\mathrm{n}}\right)$, which are called soft segments (Table 2). Because of the advantageous elasticity, the film formation is better and shrinking joints are less commonly developed than with the SAE. The size of the gel plates can be variable because of the negligible secondary porosity (Hilbert 1999). The Chinese terracotta army was consolidated by using the eSAE (Utz 2004). Pfefferkorn and Siedel (2001) have shown that in the sandstone of the Zwinger palace (Dresden, Germany) the eSAE proved to be more appropriate, while the traditional SAE did not achieve the desired results.

The best known and chemically most stable acrylate resin is the polymethyl methacrylate (PMMA). It is applied as a solution that is diluted by $5-15 \%$ xylol. The acrylate evolves a strengthening effect after evaporation of the solvent due to a film layer on the treated surface (Snethlage 1984). The solvent is recommended for usage in carbonates like limestone and marble, for filling and closure of smaller pore spaces and fissures (Snethlage 2005). Acrylate resin can induce a darkening of the treated surface (Auras 2000). Curing with acrylic resin is theoretically reversible; however, experience have shown that the acrylic resin film is not removable from the pore wall (Snethlage 1984). The water repellence of the stone surface increases when the acrylate resin is used (Weber 1983). Acrylate resin was successfully applied in the Cathedral of Lausanne (Furlan and Félix 2000); however, at the world heritage site of Angkor Vat in Cambodia it caused damage, which was later corrected (Leisen and von 
Plehwe-Leisen 2005). According to Auras (2000), the use of SAEs was more effective than the acrylate resins for consolidating the limestones of Maria Church in Muehlhausen. However, Ettl et al. (2006) obtained a more effective strengthening on marble surfaces with acrylate resin than by applying SAE. The method of acrylate resin saturation (Snethlage 2005) is applicable in the case of movable sculptures and artworks (Grassegger 2002). Grimm (2005) considers the Ibach Method (Ibach and Ibach 2005; Lorenz and Ibach 1999) as the only saving alternative for valuable, but strongly damaged stone materials. The properties of the various stone consolidants are summarised in Table 2.

\section{Methods}

\section{Experiments}

Test specimens were drilled and cut from stone blocks that were taken from the five quarries. In order to take into consideration the fabric of the natural building stones and the orientation and foliation, the samples were drilled and cut in three different directions. Therefore, a reference coordinate system with respect to the macroscopically visible bedding was chosen $(x, y, z)$ and were noted for all specimens.

The specimens were then divided into test groups. For reference, two sets of samples for each analysis were left untreated, while the rest of the specimens were treated. One set was studied air-dry, while the other set was analysed after water saturation. At the beginning, before the application of the stone consolidants (SAE, eSAE and PMMA) all the samples, except the reference set, were treated with an anti-hygro product to decrease the swelling ability of any clay minerals present, and to have a more effective treatment. The samples were saturated with anti-hygro by using vacuum impregnation. After this treatment the samples were left drying for 2 weeks. When all the treated samples were dried vacuum impregnation was applied to fully saturate the samples with the consolidants (SAE, eSAE, PMMA). The analyses were carried out after a long period of drying, i.e. the specimens remained under laboratory conditions until constant weight. For measuring the effectiveness of consolidation and to study the changes in stone properties all tested parameters were determined before and after consolidation.

\section{Analyses}

The mineral compositions and textures of the studied stones were characterised by using a Leica DMRX pola- rising microscope. In order to visualise the penetration of the stone consolidants, besides using optical microscopy, SEM analyses were performed on gold-coated samples using a LEO 1530 Gemini field emission scanning electron microscope. The porosity of treated and untreated samples was measured according to the EN 1936:2000 on cylindrical samples (Ø $40 \mathrm{~mm} / 20 \mathrm{~mm}$ ) and on cubic specimens. The pore radii distribution of the tuffs was detected via mercury pressure porosimetry by using cylindrical samples $(\varnothing 10 \mathrm{~mm} / 15 \mathrm{~mm}$, Carlo Erba 2000 porosimeter). Water- and moisture transport properties of the tuffs were analysed before and after consolidation on cubic specimens with a size of $650 \mathrm{~mm}$. Samples were tested parallel and perpendicular to the foliation according to the EN 13755:2002. Water absorption experiments were accomplished in a climate chamber (Feutron KPK $400)$ on cylindrical samples $(\varnothing 15 \mathrm{~mm} / 50 \mathrm{~mm}$ ) with a constant temperature of $30^{\circ} \mathrm{C}$. The samples were exposed in a stepwise increase of relative air moisture from 15 to $95 \%$ with steps of $10 \%$ was used. The change of sample weight was recorded after equilibration with the air moisture.

Indirect tensile strength tests were carried out according to the DIN 22024. Cylindrical samples ( $\varnothing 40 \mathrm{~mm}$, length: $20 \mathrm{~mm}$ ) of natural and consolidated stones were used for the Brazilian Test.

Ultrasonic wave velocities of natural and consolidated cubic tuff samples $(65 \mathrm{~mm}$ in size $)$ were recorded according to the EN 14579:2005. The experimental setup was a GeoTron UKS 12 system, which includes a USG 40 wave generator, a UPG-250 piezoceramic signal emitter, a UPE receiver, a GeoTron VV41 signal amplifier and a Fluke 192 oscilloscope. Clay was used as a coupling medium.

The influence of water on the behaviour of natural and consolidated tuffs was determined by hygric dilatation tests in a climate chamber (Feutron KPK 400) on cylindrical specimens $(\varnothing 15 \mathrm{~mm} / 50 \mathrm{~mm})$, at $95 \%$ relative humidity in the direction of the $x$ and $z$ axes.

The long-time behaviour of stones and consolidated stone structures is often controlled by the differential thermal expansion. To understand the influence of consolidants on the thermal behaviour of tuffs, thermal dilatation tests were made according to the EN 14581:2005 by means of an individual 6 channel inductive dilatometer on cylindrical specimens (Ø $12.5 \mathrm{~mm}$; length $50 \mathrm{~mm}$ ) along the $x$ and $z$ axes (for details, see Strohmeyer 2003). The specimens were heated uniformly with a temperature change of $0.75^{\circ} \mathrm{C} / \mathrm{min}$ from $20^{\circ} \mathrm{C}$ to $90 / 99^{\circ} \mathrm{C}$ and slowly cooled down to room temperature. For all the investigated samples the expansion coefficient as well as the total dilatation were determined. 


\section{Results}

SEM analyses

The SAE was observed in the pore space of all samples by SEM analyses. The SAE partly occludes the pore space, creating larger gel plates. A typical micro-fissure system within the consolidant is also observed (Fig. 4a). The SAE structure is represented by broken, polygonal fragments of varying sizes (Fig. 4). The length of the edges of these fragments is about $5 \mu \mathrm{m}$, which cause an increase in the surface area. This appearance is a consequence of a reduction of volume and results from the chemical properties of the silicic acid ester. Due to the permanent progressional hydrolysis in the SAE a typical fissure system develops (Fig. 4b), which creates a secondary porosity. SAE can also be observed as an "intrusion" into the small pores within the clayey matrix of the tuffs (Fig. 4c).

Visualisation of the eSAE is more difficult by the SEM. However, inside the pores of the WE tuff and RO tuff the consolidant could be detected (Fig. 4e). The EDX analyses conducted also proved the presence of eSAE. Larger gel plates, which are common in the SAE treated samples, are not observed in eSAE treated specimens. A characteristic fissure system is observable within the eSAE, which is similar in size to that found in SAE treated samples. This is also caused by progressive hydrolysis. Fewer polygonal fragments are found in samples with the eSAE, as compared to those in SAE treated samples.

The detection of PMMA proved to be very difficult because of the low substance content $(10 \%)$. The best way to detect PMMA was with the use of EDX-measurements, because the X-ray spectrum of PMMA shows a characteristic C-peak. In the tuff samples the PMMA creates typical leaflet-like fragments (Fig. 4f), which are lying isolated on mineral surfaces. The size varies between 1 and $15 \mu \mathrm{m}$. In the HA tuff completely filled pores were also observed.

\section{Pore-size distribution}

The highly porous WE tuff (43\%) shows an inhomogeneous pore radii distribution, with a well-pronounced maximum in the capillary pore range of $1.60-2.50 \mu \mathrm{m}$ as well as a submaximum of $6-12 \mathrm{~nm}$ (Fig. 5a). The HA tuff has the lowest porosity of $22.01 \%$. Its pore radii maximum of micropores ranges $4-6 \mathrm{~nm}$. The submaximum is weakly pronounced with capillary pores ranging $10-15 \mu \mathrm{m}$. The RO tuff has a porosity of $28.27 \%$. It shows a bimodal pore radii distribution with a maximum micropore range of 80 $100 \mathrm{~nm}$ and a capillary pore range of $2-4 \mu \mathrm{m}$. The two Hungarian tuffs exhibit a similar porosity (Table 3). However, the pore radii distribution is different. Whereas the ED is characterised by micropores, the ET tuff is
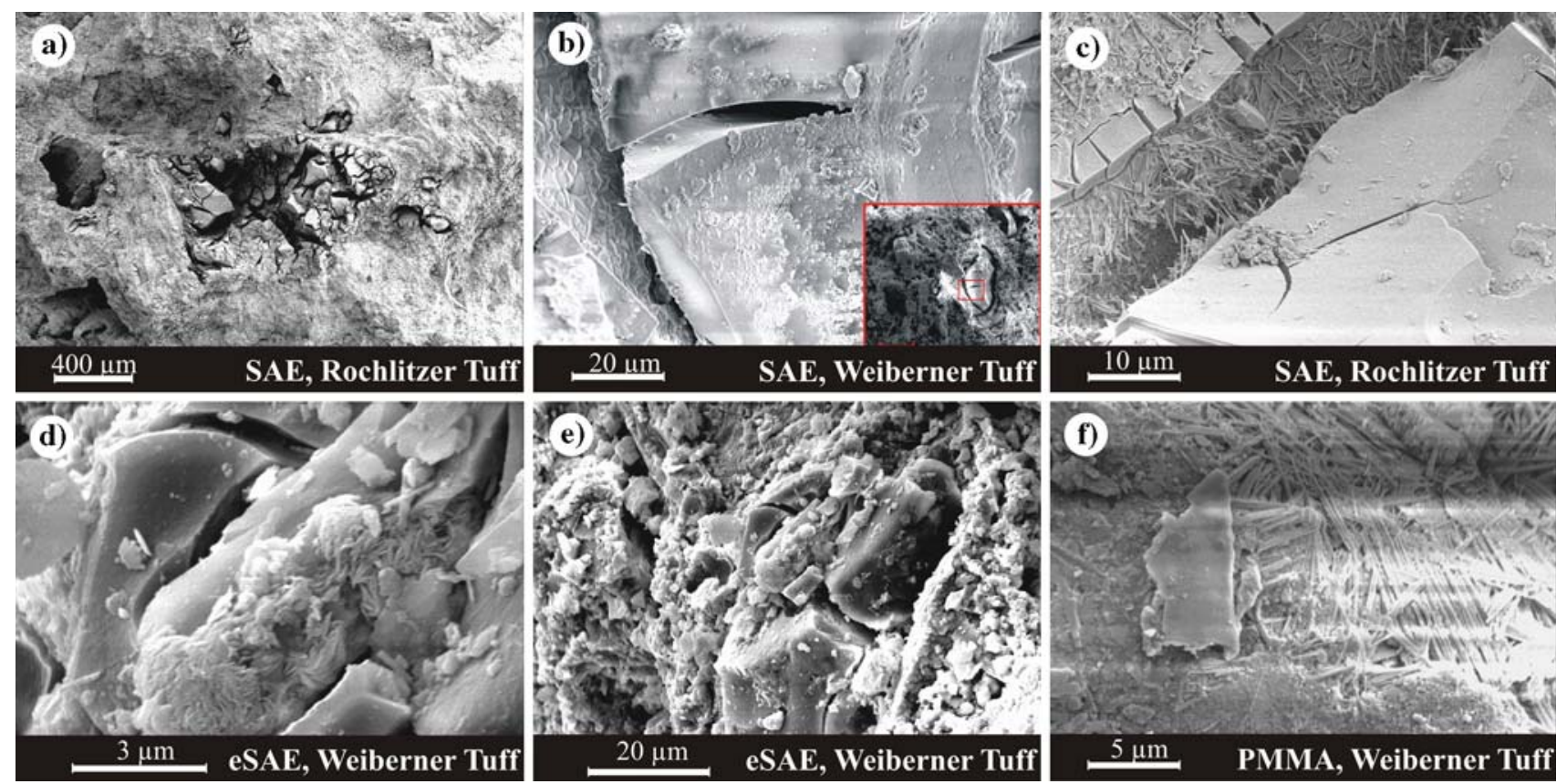

Fig. 4 Visualisation of the consolidants SAE, eSAE and PMMA in pore spaces under the SEM: a once completely filled pore, which after advanced hydrolysis shows a secondary porosity, b internal fissure system at the consolidant surface, $\mathbf{c}$ invaded silica acid ester in a clay mineral matrix of the RO tuff, $\mathbf{d}$ polygonal fragment of eSAE, $\mathbf{e}$ invaded, more rounded material of eSAE in a pore space, and $\mathbf{f}$ a single, covering fragment of PMMA over zeolitic minerals 
characterised by a maximum of capillary pores (Török et al. 2007).

The porosities and pore radii are completely different from the consolidated samples. The consolidants produce a specific change in the pore space, with the porosity of all the samples decreasing at about the same degree. The porosity decreased the most in SAE treated samples, where a reduction of about $25 \%$ was measured. The eSAE and PMMA consolidants reduce the porosity by more than $15 \%$.

Fig. 5 Pore radii distribution and weight change in the Weiberner tuff. Pore radii distribution of: a natural state, $\mathbf{b}$ SAE treated, $\mathbf{c}$ eSAE treated and d PMMA treated specimens. Sorption and desorption isotherms of the Weiberner tuff in: e natural state, f SAE treated, g eSAE treated and $\mathbf{h}$ PMMA treated specimens
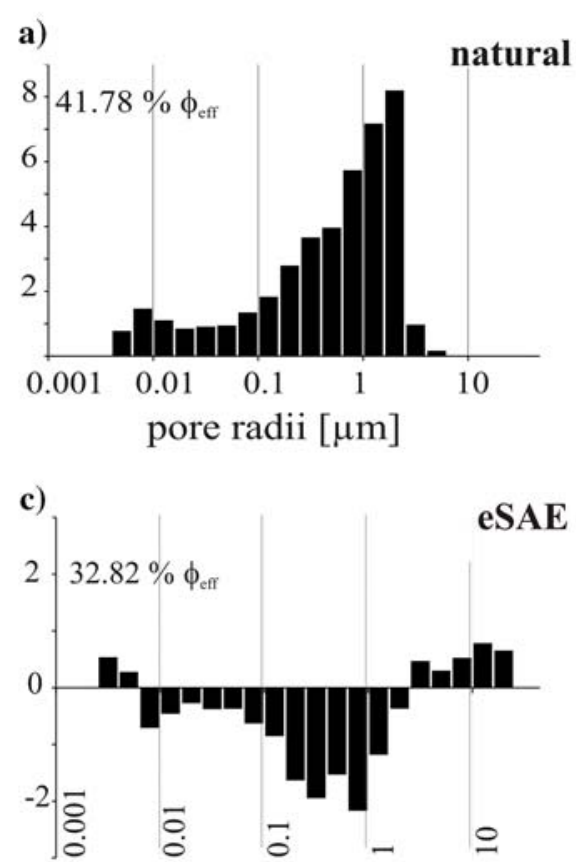

pore radii $[\mu \mathrm{m}]$
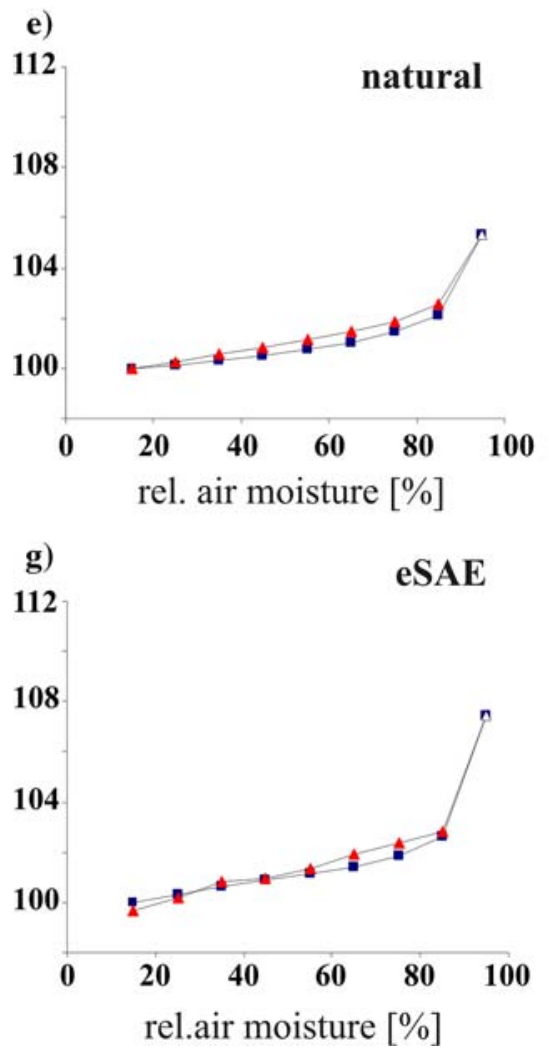
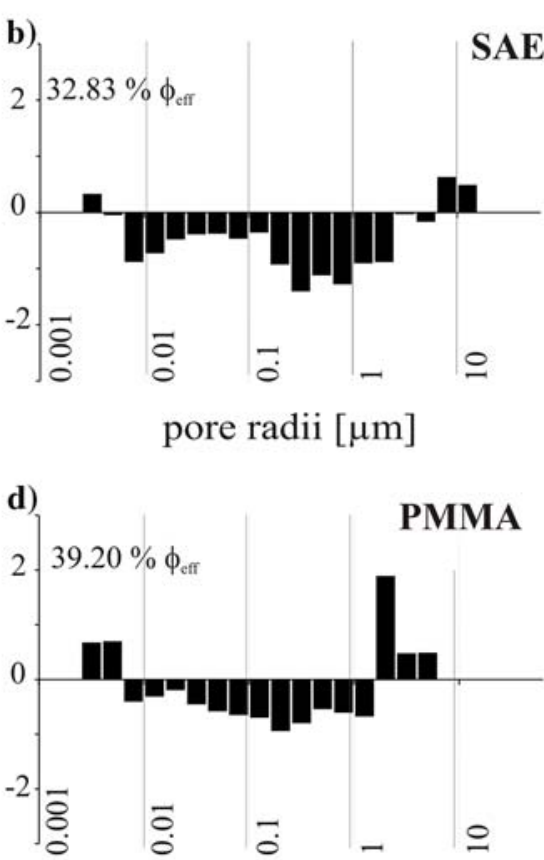

pore radii $[\mu \mathrm{m}]$
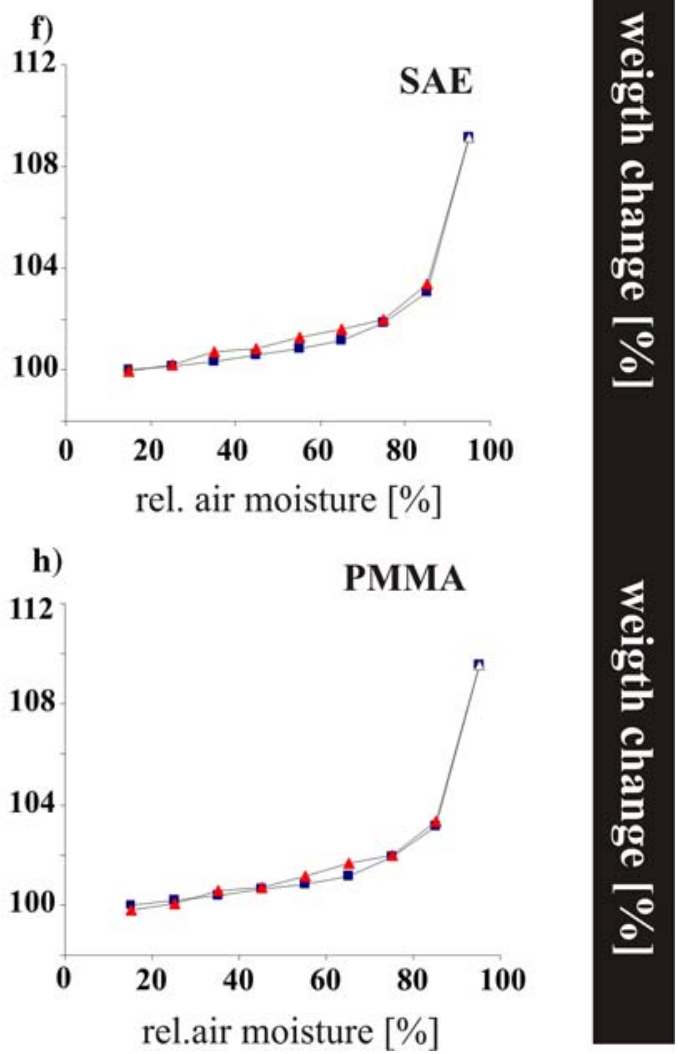
Table 3 Petrophysical properties and their determined values of the various tuffs in natural state and after stone consolidation

\begin{tabular}{|c|c|c|c|c|c|c|c|c|c|c|}
\hline & \multicolumn{2}{|c|}{ Eger-Tihamér } & \multicolumn{2}{|l|}{ Weibern } & \multicolumn{2}{|l|}{ Rochlitz } & \multicolumn{2}{|c|}{ Habichtswald } & \multicolumn{2}{|c|}{ Eger-Demjén } \\
\hline & Ave & Std & Ave & Std & Ave & Std & Ave & Std & Ave & Std \\
\hline \multicolumn{11}{|c|}{ Effect. porosity (vol.\%) } \\
\hline Natural & 36.00 & 0.2 & 43.08 & 0.4 & 28.27 & 0.5 & 22.01 & 1.3 & 34.76 & 0.1 \\
\hline SAE & 27.86 & 0.7 & 31.30 & 0.9 & 20.90 & 0.9 & 16.37 & 0.4 & 25.71 & 0.0 \\
\hline eSAE & 29.79 & 0.1 & 35.98 & 0.5 & 23.30 & 0.4 & 19.66 & 0.4 & 28.23 & 0.1 \\
\hline PMMA & 28.45 & 0.6 & 37.25 & 0.2 & 24.77 & 0.2 & 19.76 & 0.9 & 27.38 & 0.3 \\
\hline \multicolumn{11}{|c|}{ Density $\left(\mathrm{g} / \mathrm{cm}^{3}\right)$} \\
\hline Natural & 1.532 & & 1.423 & & 1.971 & & 2.195 & & 1.653 & \\
\hline Water $_{\mathrm{vac}}$ & 1.797 & & 1.835 & & 2.154 & & 2.359 & & 1.967 & \\
\hline SAE & 1.673 & & 1.595 & & 2.046 & & 2.245 & & 1.751 & \\
\hline eSAE & 1.594 & & 1.535 & & 2.001 & & 2.214 & & 1.669 & \\
\hline PMMA & 1.573 & & 1.534 & & 1.964 & & 2.237 & & 1.646 & \\
\hline \multicolumn{11}{|c|}{ Tensile strength (Mpa) } \\
\hline Natural & 0.814 & 0.14 & 1.636 & 0.22 & 2.423 & 0.28 & 2.676 & 0.91 & 3.300 & 0.57 \\
\hline Water $_{\text {vac }}$ & 0.314 & 0.08 & 1.234 & 0.14 & 1.472 & 0.26 & 2.374 & 0.60 & 2.784 & 0.36 \\
\hline SAE & 1.558 & 0.34 & 2.619 & 0.41 & 3.577 & 0.61 & 3.683 & 0.96 & 4.208 & 0.72 \\
\hline ESAE & 1.538 & 0.33 & 2.180 & 0.40 & 3.264 & 0.65 & 3.281 & 0.90 & 3.847 & 0.75 \\
\hline PMMA & 1.201 & 0.14 & 2.074 & 0.19 & 3.281 & 0.90 & 3.149 & 0.66 & 3.207 & 0.51 \\
\hline \multicolumn{11}{|c|}{ US velocity $(\mathrm{km} / \mathrm{s})$} \\
\hline Natural & 1.896 & 0.06 & 2.276 & 0.02 & 3.059 & 0.02 & 2.526 & 0.12 & 2.710 & 0.06 \\
\hline Water $_{\mathrm{vac}}$ & 2.055 & 0.14 & 2.457 & 0.08 & 3.335 & 0.05 & 3.729 & 0.16 & 2.992 & 0.04 \\
\hline SAE & 2.141 & 0.06 & 2.266 & 0.07 & 3.069 & 0.06 & 3.135 & 0.19 & 2.858 & 0.06 \\
\hline ESAE & 1.987 & 0.08 & 2.263 & 0.04 & 3.043 & 0.06 & 2.654 & 0.11 & 2.843 & 0.04 \\
\hline PMMA & 2.078 & 0.09 & 2.373 & 0.05 & 3.107 & 0.10 & 2.787 & 0.17 & 2.858 & 0.07 \\
\hline $\begin{array}{l}\text { W-value } \\
\left(\mathrm{kg} / \mathrm{m}^{2} * \sqrt{\mathrm{h}}\right)\end{array}$ & $x$ & $z$ & $x$ & $z$ & $x$ & $z$ & $x$ & $z$ & $x$ & $z$ \\
\hline Natural & 11.34 & 11.09 & 16.45 & 16.28 & 3.51 & 3.21 & 2.10 & 1.87 & 8.54 & 8.85 \\
\hline SAE & 6.04 & 4.78 & 4.39 & 3.45 & 1.78 & 1.52 & 1.23 & 1.05 & 3.75 & 2.94 \\
\hline eSAE & 7.81 & 7.44 & 7.46 & 7.00 & 2.04 & 1.78 & 1.82 & 1.50 & 4.18 & 3.11 \\
\hline PMMA & 0.25 & 0.28 & 0.41 & 0.31 & 1.57 & 1.52 & 0.40 & 0.29 & 0.33 & 0.26 \\
\hline
\end{tabular}

Water and moisture uptake

The most important physical properties measured in the tuffs are listed in Table 3. The water uptake of the WE tuff and the ET tuff was very rapid and it was complete after $20 \mathrm{~min}$. Thus, the high $\mathrm{w}$-values of $16.45,11.34 \mathrm{~kg} / \mathrm{m}^{2} * \sqrt{\mathrm{h}}$ for $x$-direction, and $16.28,11.09 \mathrm{~kg} / \mathrm{m}^{2} * \sqrt{\mathrm{h}}$ for $z$-direction, respectively, indicate a rapid and high rate of water penetration. The water uptake is slower in the HA and RO tuffs, since $24 \mathrm{~h}$ was needed for full water saturation (means $\left.1.98,3.36 \mathrm{~kg} / \mathrm{m}^{2} * \sqrt{\mathrm{h}}\right)$. The ED tuff with a value of $8.69 \mathrm{~kg} / \mathrm{m}^{2} * \sqrt{\mathrm{h}}$ shows a much slower water uptake to the petrologically similar ET tuff. For all the samples a clearly pronounced anisotropy was detected. The water uptake parallel to $x$-direction was larger than that in $z$-direction
(Table 3). For consolidated samples in every case a decrease of $\mathrm{w}$-values and a decelerated water uptake was measured. The PMMA treatment produced a very distinct reduction in the water uptake, up to $98 \%$, whereas the treatment with SAE resulted in a lower reduction. Thus SAE treated samples decreased the water uptake by $45 \%$ (HA tuff) to $76 \%$ (WE tuff). The consolidation with eSAE shows a comparable trend. For example the HA tuff has the lowest decrease in capillary water uptake of $17.5 \%$. This is followed by ET and RO tuffs with a reduction of 42 and $43 \%$, respectively.

The weight of the non-treated tuffs at a relative humidity of $95 \%$ as compared to the initial weight increased between 1.4 and $5.3 \%$. The very porous WE tuff (Fig. 5e) and HA tuff show similar high values (Table 3 ). In contrast, the 
RO, ET and ED tuffs are in the lower range of weight increase, which was between 1.4 and $1.5 \%$.

All tuffs, except the HA show a weight increase when natural samples and consolidated samples are compared. The most significant weight gain at various relative humidities was observed in eSAE treated samples, which were followed by SAE treated samples. The lowest increase was measured in the PMMA treated samples with the exception of the WE tuff, where eSAE caused the smallest increase when untreated and treated samples were compared under humid conditions (Fig. 5).

\section{Tensile strength}

The tensile strength of non-treated samples varies between $0.8 \mathrm{MPa}$ (ET tuff) and 3.3 MPa (ED tuff) (Table 3). The wide spectrum of results is in accordance with the significant standard deviation, i.e. strong variation of results of individual measurement, which is attributed to the inhomogeneity of the stones. In all the consolidations the tensile strength increases, whereas the degree of the change depends on the type of consolidant. All the samples treated with SAE showed the most significant tensile strength increase, which was followed by eSAE. Consolidation with PMMA exerts the lowest strengthening effect. The measurements, carried out in three perpendicular directions, have shown that the anisotropy of the tensile strength is persistent despite the consolidation. Thus, both the nonconsolidated and consolidated samples show the same kind of anisotropy. Water content decreased the tensile strength considerably, both in natural and in consolidated stones (Table 3).

\section{Ultrasonic wave velocities}

The values of ultrasonic wave velocities of natural stones vary between $1.89 \mathrm{~km} / \mathrm{s}$ (ET tuff) and $3.065 \mathrm{~km} / \mathrm{s}$ (RO tuff) (Table 3). The ultrasonic wave moves faster in water saturated samples. The measured values are in the range of $2.055 \mathrm{~km} / \mathrm{s}$ (ET tuff) to 3.73 (HA tuff). The ultrasonic wave velocities of consolidated samples are in general more similar to the water saturated samples, than to natural ones. Nevertheless, major differences are found between the water-saturated and the PMMA consolidated samples of HA and RO tuffs.

\section{Hygric dilatation}

The hygric dilatation of the unconsolidated sample of the WE tuff is in average $0.54 \mathrm{~mm} / \mathrm{m}$ and shows a slight anisotropy, which also persists after consolidation. Through the consolidation with SAE and eSAE the hygric dilatation increases, in the case of SAE more so than in the

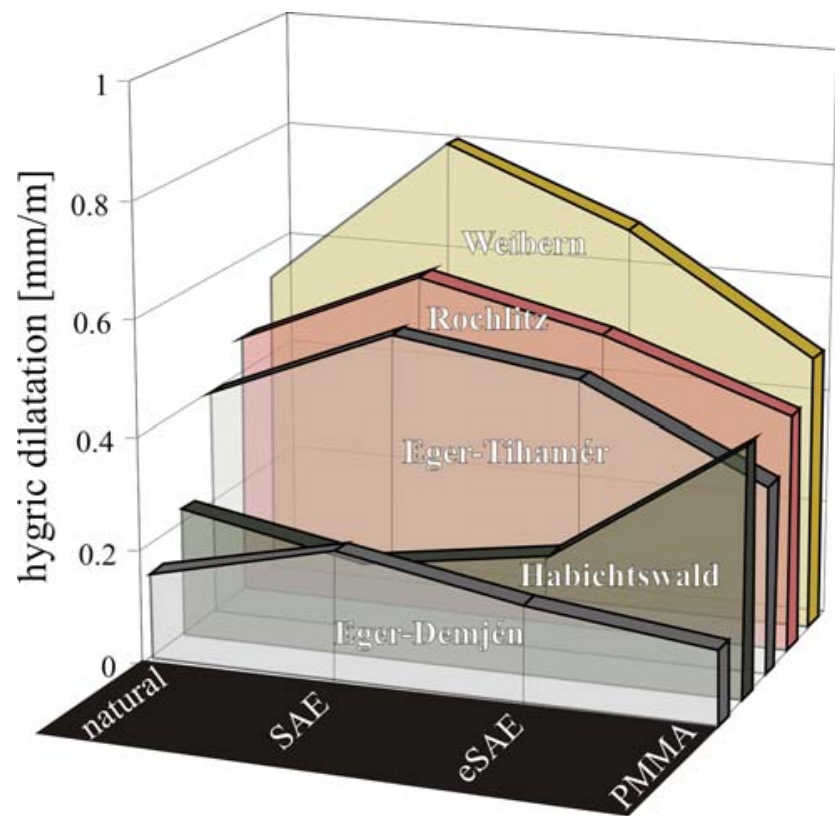

Fig. 6 Diagram of hygric dilatation of the investigated tuffs. The length changes of natural stones are compared to the SAE, elastic SAE and PMMA consolidated ones

case of eSAE. The PMMA has an opposite effect as it reduces the hygric dilatation (Fig. 6).

Despite the swelling clay content the HA tuff has a low hygric extension (mean: $0.23 \mathrm{~mm} / \mathrm{m}$ ) in contrast to the WE tuff (Table 4). Its anisotropy is less pronounced. When the HA tuff is treated with SAE the hygric dilatation is reduced, with a weak permanent anisotropy. The eSAE consolidated sample behaves similarly to the unconsolidated sample. In contrast, the PMMA treated sample shows a clear increase of dilatation.

The RO tuff has a very large hygric dilatation at $95 \%$ air humidity (mean: $0.46 \mathrm{~mm} / \mathrm{m}$ ). Anisotropy is similarly weak in the HA tuff, thus it is not pronounced at all. The SAE and eSAE cause an increase in the hygric dilatation, while PMMA reduces the dilatation.

The unconsolidated ED tuff shows a minor hygric dilatation, with a clear anisotropy. The consolidation does not modify significantly the behaviour of the tuff, and hygric dilatation remains nearly the same. The SAE and eSAE increases, while PMMA decreases the hygric dilatation (Fig. 6). This is similar to the trend observed for the WE and RO tuffs.

The ET tuff exhibits an average hygric dilatation of $0.40 \mathrm{~mm} / \mathrm{m}$, with a considerable anisotropy. When the ET tuff is consolidated with SAE and eSAE, the hygric dilatation is clearly increased and the anisotropy persists (Table 4). The PMMA consolidated sample in contrast shows a considerable reduction of the hygric dilatation (Fig. 6). 


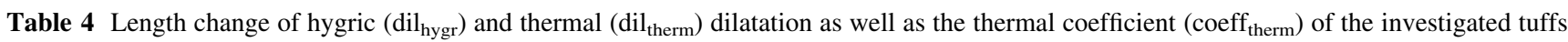

\begin{tabular}{|c|c|c|c|c|c|c|c|c|c|c|c|c|c|c|c|}
\hline \multirow[t]{2}{*}{ Stone type } & \multicolumn{3}{|l|}{ ET } & \multicolumn{3}{|l|}{ WE } & \multicolumn{3}{|l|}{ RO } & \multicolumn{3}{|l|}{ HA } & \multicolumn{3}{|l|}{ ED } \\
\hline & $x$ & $z$ & Ave & $x$ & $z$ & Ave & $x$ & $z$ & Ave & $x$ & $z$ & Ave & $x$ & $z$ & Ave \\
\hline \multicolumn{16}{|c|}{$\operatorname{dil}_{\text {hygr }} 95 \%(\mathrm{~mm} / \mathrm{m})$} \\
\hline Natural & 0.33 & 0.46 & 0.38 & 0.49 & 0.59 & 0.54 & 0.45 & 0.47 & 0.46 & 0.22 & 0.23 & 0.23 & 0.11 & 0.19 & 0.15 \\
\hline SAE & 0.44 & 0.62 & 0.53 & 0.76 & 0.85 & 0.80 & 0.59 & 0.61 & 0.60 & 0.16 & 0.17 & 0.17 & 0.14 & 0.31 & 0.23 \\
\hline eSAE & 0.40 & 0.56 & 0.48 & 0.65 & 0.71 & 0.68 & 0.47 & 0.58 & 0.53 & 0.21 & 0.22 & 0.22 & 0.10 & 0.24 & 0.17 \\
\hline PMMA & 0.29 & 0.37 & 0.33 & 0.43 & 0.53 & 0.48 & 0.40 & 0.43 & 0.42 & 0.39 & 0.48 & 0.44 & 0.09 & 0.17 & 0.13 \\
\hline \multicolumn{16}{|c|}{$\operatorname{dil}_{\text {therm }}(\mathrm{mm} / \mathrm{m})$} \\
\hline Natural & 0.21 & 0.16 & 0.19 & 0.10 & 0.10 & 0.12 & 0.31 & 0.31 & 0.31 & 0.28 & 0.33 & 0.31 & 0.28 & 0.27 & 0.28 \\
\hline SAE & 0.32 & 0.26 & 0.29 & 0.14 & 0.14 & 0.14 & 0.46 & 0.34 & 0.40 & 0.33 & 0.40 & 0.37 & 0.29 & 0.28 & 0.29 \\
\hline eSAE & 0.33 & 0.3 & 0.32 & 0.20 & 0.07 & 0.14 & 0.34 & 0.35 & 0.35 & 0.36 & 0.36 & 0.36 & 0.29 & 0.28 & 0.29 \\
\hline PMMA & 0.37 & 0.27 & 0.32 & 0.19 & 0.09 & 0.14 & 0.52 & 0.32 & 0.42 & 0.42 & 0.45 & 0.44 & 0.36 & 0.33 & 0.35 \\
\hline \multicolumn{16}{|c|}{$\operatorname{coeff}_{\text {therm }}\left(10^{-6} \mathrm{~K}^{-1}\right)$} \\
\hline Natural & 3.65 & 3.7 & 3.68 & 5.72 & 6.09 & 5.90 & 7.44 & 7.74 & 7.59 & 7.54 & 7.61 & 7.58 & 4.64 & 4.89 & 4.76 \\
\hline SAE & 5.85 & 6.15 & 6.00 & 7.23 & 7.49 & 7.36 & 9.06 & 9.16 & 9.11 & 6.76 & 7.22 & 6.99 & 5.52 & 5.48 & 5.50 \\
\hline eSAE & 3.68 & 3.34 & 3.51 & 7.20 & 7.70 & 7.45 & 9.08 & 9.25 & 9.17 & 7.45 & 7.52 & 7.49 & 5.46 & 5.4 & 5.43 \\
\hline PMMA & 7.67 & 5.75 & 6.71 & 7.68 & 7.20 & 7.44 & 10.75 & 9.25 & 10.0 & 9.07 & 8.50 & 8.79 & 6.62 & 6.51 & 6.57 \\
\hline
\end{tabular}

Thermal dilatation

The expansion behaviour with increasing temperature for all samples is similar, and is characterised by a linear continuous expansion until a temperature of $75-85^{\circ} \mathrm{C}$. After this the dilatation to a temperature of $90^{\circ} \mathrm{C}$ decreases. The further linear contraction during the cool-down period proceeds until $25^{\circ} \mathrm{C}$. The dilatation changes from 25 to $20^{\circ} \mathrm{C}$ and then shows an expansion again.

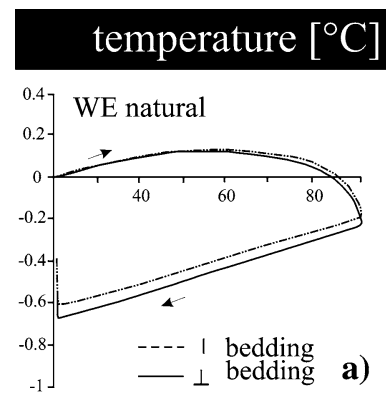

\section{temperature $\left[{ }^{\circ} \mathrm{C}\right]$}

a)
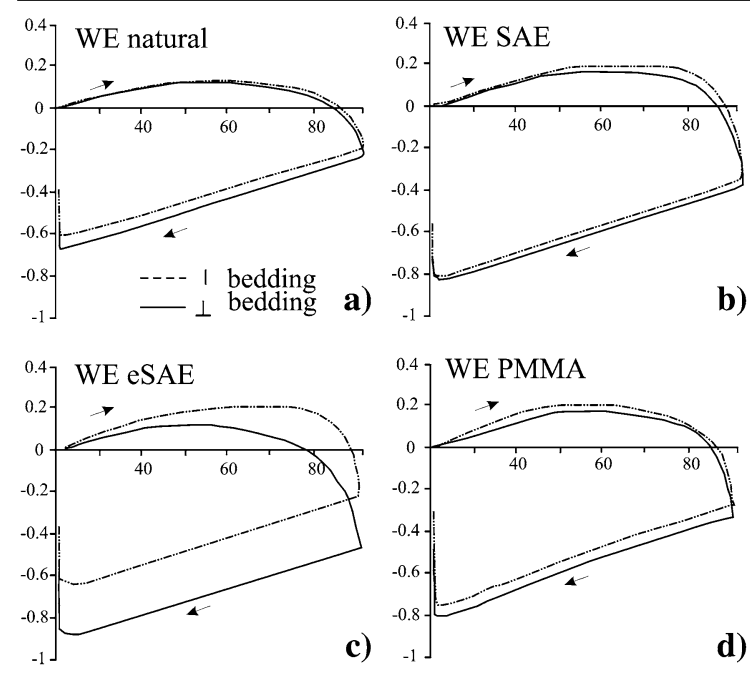

c)

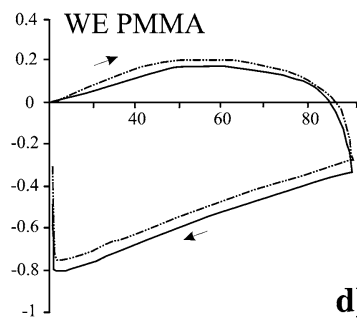

d)

Fig. 7 Thermal dilatation of the Weiberner tuff. Length change behaviour at a natural, b SAE treated, c eSAE treated and d PMMA treated sample. The relationship between temperature and length change remains similar, although the magnitude may clearly differ
In general the consolidants cause changes in thermal dilatation for all samples. The relationship between temperature and length change remains similar, although the magnitude may differ (Fig. 7).

The WE tuff has a maximal dilatation of about $0.12 \mathrm{~mm} /$ $\mathrm{m}$ in the temperature range of $50-60^{\circ} \mathrm{C}$. This is followed by a contraction of $-0.20 \mathrm{~mm} / \mathrm{m}$, which is caused by a volume loss in the clay minerals (Fig. 7). The consolidated samples show progressive expansion and contraction phases, thus the consolidant increases the ability of dilatation. The thermal expansion coefficient shows the same trend. It becomes larger in all the consolidated samples than that in the unconsolidated ones (Table 4).

The HA tuff shows in the unconsolidated state a more intense length change and a coeval lower contraction during the water loss of the clay minerals than the WE tuff (Table 4). The contraction begins at $85^{\circ} \mathrm{C}$. The linear gradient during cooling-down reaches a maximal contraction of $-0.20 \mathrm{~mm} / \mathrm{m}$, and is followed at a temperature of $25^{\circ} \mathrm{C}$ by an equilibration with air moisture. The samples which were consolidated by SAE and eSAE show an increase of thermal dilatation values (Table 4). An opposite trend was measured for the thermal expansion coefficients (Table 4). At the same time the samples show an increase of the clay mineral caused contraction, which is $-0.28 \mathrm{~mm} / \mathrm{m}$ for SAE and $-0.30 \mathrm{~mm} / \mathrm{m}$ for eSAE treated samples, respectively. The PMMA treated samples behave differently; the expansion is higher and the contraction lower. The contraction above $85^{\circ} \mathrm{C}$ is lower $(-0.18 \mathrm{~mm} / \mathrm{m})$ than that of in the unconsolidated state.

The length change of unconsolidated RO tuff is characterised by an initial intense expansion which is reduced 
afterwards. At a temperature of $55^{\circ} \mathrm{C}$ the expansion coefficient changes from $7.5 \times 10^{-6} \mathrm{~K}^{-1}$ to $5.8 \times 10^{-6} \mathrm{~K}^{-1}$ (in average). This causes a total dilatation of $+0.36 \mathrm{~mm} / \mathrm{m}$ at a temperature of $90^{\circ} \mathrm{C}$. When the samples are cooling and they reach the temperature of $25^{\circ} \mathrm{C}$ a contraction of $-0.28 \mathrm{~mm} / \mathrm{m}$ is measured, which is followed by expansion through equilibration. The consolidated samples behave similarly to the untreated ones, but having an increased maximum dilatation.

The maximum expansion of the unconsolidated ED tuff is $0.28 \mathrm{~mm} / \mathrm{m}$ with an expansion coefficient of $4.76 \times 10^{-6} \mathrm{~K}^{-1}$ in average. During the linear cooling the sample is contracted by $-0.15 \mathrm{~mm} / \mathrm{m}$. The SAE and eSAE treated samples have a slightly larger maximum dilatation (mean: $0.29 \mathrm{~mm} / \mathrm{m}$ ). In contrast, the PMMA consolidated sample shows a length change of $0.35 \mathrm{~mm} / \mathrm{m}$, which is more than the unconsolidated one. The expansion coefficient is also increased $\left(6.56 \times 10^{-6} \mathrm{~K}^{-1}\right.$ in average $)$ as compared to the non-treated samples $\left(4.77 \times 10^{-6} \mathrm{~K}^{-1}\right.$ in average) (Table 4). The contraction above $85^{\circ} \mathrm{C}$ in all consolidated samples is increased compared with the nontreated ones. Especially the SAE and eSAE treated samples have high values of -0.27 and $-0.26 \mathrm{~mm} / \mathrm{m}$, respectively, whereas the PMMA treated sample has a smaller value of about $-0.2 \mathrm{~mm} / \mathrm{m}$.

The length change of the ET tuff is characterised by an early water loss $\left(70^{\circ} \mathrm{C}\right)$ in clay minerals, and a thus a weaker contraction during the cooling down as compared to the other tuffs. The total dilatation of the unconsolidated ET tuff is $0.18 \mathrm{~mm} / \mathrm{m}$ in average with an expansion coefficient of $3.67 \times 10^{-6} \mathrm{~K}^{-1}$ (mean) (Table 4). The consolidated samples show significant changes in dilatation. All consolidants cause an increase in dilatation and the expansion coefficient. The smallest changes are related to eSAE. The contraction during the cooling process is characterised by approximately constant and similar values for all consolidants $(-0.16 \mathrm{~mm} / \mathrm{m})$.

\section{Discussion}

The consolidation caused major changes in the behaviour of the tuffs. The pore size distribution analyses have shown that for all consolidants a change in pore size distribution took place. After consolidation the most frequent pore size radii is significantly decreased. The Weibern tuff shows an additional increase of a given pore size range (Fig. 5b-d). The various consolidants have different abilities to fill the pores. The characteristic effect of SAE treatment is a reduction of micropores, which results from the molecule size of the chemical agent ( $3 \mathrm{~nm}$ ) (Fig. $5 b$ ). In contrast, the eSAE treatment causes a lower reduction of micropores, and in some cases an increase of small micropores can be detected. This can be attributed to the chemical property of eSAE, because the precipitation of silica gels has a larger molecule size as the consolidant develops (Hilbert 1999). As a consequence it fills larger pores causing a shift in pore size distribution toward the smaller pores. The treatment with PMMA in most cases also causes a reduction in the micropores. These changes however are not uniform. There is a marked difference in the WE tuff. The $41.8 \%$ of the original porosity is reduced by $8.9 \%$ due to $\mathrm{SAE}$, and also by eSAE. In contrast, the PMMA only caused a $2.6 \%$ drop in porosity. These different trends are not observed for the other tuffs, for example the PMMA treatment caused a $10.3 \%$ drop in porosity, while eSAE only reduced the porosity of the HA tuff only by $10.1 \%$. These discrepancies are clearly attributed to differences in the pore size distribution of the WE and HA tuffs. In the HA tuff micropores dominate, while in the WE tuff capillary pores are the most common. Thus it seems that eSAE can fill larger pores, while the pore-filling ability of PMMA is less pronounced. This is contradicted by the fact that the average molecule size of PMMA is more than four times larger $(24 \mathrm{~nm})$ than that of the eSAE $(1.2-6 \mathrm{~nm})$. This apparent contradiction can be solved by the consolidation mechanism of eSAE, because the three-dimensional silicic gel builds up in the pores forming long interconnected chains of silanol groups (Hilbert 1999; Wendler 2001).

The pore size distribution is responsible for water transport properties, and thus significantly influences the weathering ability of stones (Fitzner and Basten 1994) and especially of volcanic tuffs (Steindlberger 2004; Török et al. 2007). By filling the pore space with consolidant the pore space is inevitably modified. The decrease in porosity depends on the amount of the precipitated consolidant. The results of the pore size distribution analyses have shown that the larger capillary pores are reduced as a consequence of partial filling and closure by consolidants. Some of the consolidants not only close pores but also produce additional secondary pores. Within the precipitated SAE and eSAE, secondary pores and micro-fissures are generated due to prolonged hydrolysis (Hilbert 1999). This leads to the formation of a micron-sized secondary porosity. This is not only visible under the SEM (Fig. 4), but also becomes evident through the pore size distributions (Fig. 4). As a consequence, the change of pore size distribution depends not only on the molecule size of the particular consolidant, but also on the binding mechanism and on the post-consolidation processes acting in the consolidants.

The water uptake and water adsorption was significantly influenced by consolidation and can be related to the change in pore size distribution. Through consolidation the path for capillary water transport as well as the entry or rather the interconnection of capillary pores becomes reduced. In all samples this caused a retarded water uptake 
and therefore a reduction of the w-value (Table 3 ). A further reason for the decrease of capillary water uptake can be the hydrophobic property of the consolidant. The hydrophobic nature of PMMA has been noted previously (Price 1996; Snethlage 1997; Alvarez de Buergo and Fort 2002). All samples that were treated with PMMA show a very limited water uptake, different from the original porosity (Table 3). The lowest change of capillary water uptake is caused by eSAE. This can be attributed to the fact that secondary pores, such as micro-fissures are generated with the silica gel plates due to the hydrolysis of eSAE (Fig. 3), and thus these pores enable capillary water uptake.

The indirect tensile strength of the volcanic tuffs was inevitably increased by treatment with all types of consolidants. This increase is not proportional with the decrease in porosity. For example in the RO tuff, the eSAE and PMMA treated samples have nearly the same indirect tensile strength (3.3 MPa); the eSAE decreased the porosity by $4 \%$, while PMMA reduced the porosity only by $3.5 \%$. It is important to note that there is a scatter in the indirect tensile strength versus porosity of the natural tuffs. The ET tuff with its $36 \%$ effective porosity has a tensile strength of $0.8 \mathrm{MPa}$ on average, while the ED tuff with its $34.8 \%$ effective porosity has an indirect tensile strength which is four times higher (3.3 MPa). It was also foreseen that the consolidation is more effective when a tuff with a lower strength is treated. Indeed the tensile strength of the treated ET tuffs increased by $48-91 \%$ in consolidation depending on the consolidant (the highest values were measured on SAE treated samples). In comparison with consolidated ED tuffs, where tensile strength may decreased (PMMA), the strength slightly increased when samples were treated by SAE or eSAE (Table 3). However, the effect of rock fabrics and physical properties of unconsolidated tuffs controls the efficiency of consolidation.

Water content decreased the tensile strength considerably, both in natural and in consolidated stones. This phenomenon is attributed to a loss in strength of the stone by creation of a water film on the minerals and matrix components as well as adsorption of water molecules by clay minerals (Steindlberger 2004). This also justifies the application of anti-hygro prior to the consolidation of tuffs, because the anti-hygro reduces the swelling ability of clay (Hilbert 1999), and thus it stabilises the tuff fabric by reducing the sensitivity to weathering (Egloffstein 1998; Auras et al. 2000).

Ultrasonic wave velocities do not reflect the same trend as observed for indirect tensile strength. The water saturated samples showed an increase in sound velocities, which were higher values (except SAE treated ET) than that of the treated samples. Thus, the ultrasonic measurements showed that the increase of wave velocities is attributed to the filling of pore spaces by consolidants. As a consequence, the consolidant tends to stabilise the grain structure by filling pores and by forming bonds between grains. This is also indicated by the pore radii distribution, which shows that the consolidating SAE fills the micropores more effectively. However, the pore space of the matrix is not completely filled with the consolidant. A significant increase of the ultrasonic wave velocity is only observed in a few tuffs (ET, $\mathrm{HA}$ and ED). Increases in velocities correspond to the partial filling of pore spaces. The same trend was recognised for consolidation with PMMA.

The behaviour of tuffs during thermal stress is changed significantly by consolidation with respect to thermal dilatation and thermal coefficient (Table 4). The shapes of thermal dilatation-contraction curves are consistent, but the intensity of dilatation changes when the consolidated and natural stones are compared. For all samples, except one (WE in the ' $z$ ' direction), the thermal expansion increases by consolidation, and a higher expansion coefficient was measured. This is attributed to the partial filling of the pore space, and to the fact that the thermal expansion of clay minerals could not take place within the open pore space anymore. This decreased buffering through pore space is caused by the consolidant itself, because it forces the transfer of expansion to the stone. The increased contraction during cooling down can be also explained with the partial infilling of pores by consolidant and by modification of the active pore surface. During conditioning the samples could absorb more water and thus, more water dispenses during contraction.

The intensity of hygric dilatation of the tuffs has been suggested to depend on the swelling clay content Egloffstein (1998). Our experiments have shown that the smectite-rich HA tuff has a slower, and smaller hygric dilatation than the ET, WE or RO tuffs, although these have lower clay contents (Table 4). Thus, it is presumed that the vitreous matrix and other mineral phases such as zeolites can also influence the hygric dilatation of the tuffs. Only four tuffs (ED, ET, RO and WE) show the same trend, with respect to the hygric properties, when consolidated. When using the SAE treatment the hygric dilatation increases dramatically, while eSAE causes a less pronounced increase in most cases. In contrast, the PMMA treatment reduced the hygric dilatation of the four volcanic tuffs. All the consolidants caused opposite changes for the HA tuff. The PMMA increased the hygric dilatation, while both SAE and eSAE decreased it. One possible explanation for this trend is the anti-hygro pre-treatment before the consolidation. The higher clay content of the HA tuff enables the anti-hygro to reduce the swelling ability and water uptake of the clay minerals more effectively. Consequently the hygric dilatation is more reduced in HA tuff.

The anisotropy of hygric dilatation was consistent in samples before and after consolidation and are compared in 
Table 4. The consolidation does not change fabric properties and does not mask the textural anisotropy.

Consolidation caused changes in thermal- and hygric dilatation may explain the increased sensitivity to weathering of these tuffs. The consolidants increased the strength of all the tuffs, but in many cases decreased the long-term durability. These two contrasting phenomena are generated by the consolidation. From the point of view of durability, it is necessary to test the long-term behaviour of the consolidated tuffs, by using laboratory simulations such as hygric cycles and thermal cycles.

\section{Conclusions}

- The five tested tuffs have different fabrics and mineral compositions which significantly influence the efficiency of stone consolidating agents.

- The pore-size distribution and the efficiency of the consolidation are closely related. According to this study, SAE is able to penetrate into micropores, while eSAE can form bonds within larger micro-fissures in the tuffs. The PMMA preferentially fills the micropores. These observations are in accordance with prior studies.

- The water uptake of the consolidated tuff is influenced by the shift in pore-size distribution, by consolidation, and also by the hydrophobic nature of some consolidants. Secondary micropores were found in SAE and eSAE treated samples, while the hydrophobic affect of PMMA reduces water absorption ability the most in all investigated tuffs.

- The indirect tensile strength in all the consolidated tuff is higher than that of the natural ones. SAE caused the highest increase in tensile strength for all the studied tuff, which was followed by eSAE and PMMA.

- The ultrasonic wave velocities are not necessarily good indicators of tensile strength of consolidated tuff, because in many cases samples with higher sound velocities have lower strength.

- The consolidants increased the thermal dilatation of the tuffs. The existing anisotropies in thermal dilatation and thermal dilatation coefficient were not masked by the consolidants.

- The hygric dilatation of the consolidated tuffs versus non-treated tuffs does not show a uniform trend. SAE increased and PMMA decreased the most the hygric dilatation for all the tuffs, except for HA. The highest decrease of hygric dilatation at the smectite-rich HA tuff occurs when treated with SAE.

- The goal of the laboratory tests was to analyse the durability of the consolidated tuffs. These have shown that the modified petrophysical properties can induce significant changes in durability of the tuffs against weathering, in many cases a decreased durability. Consequently, further laboratory tests are needed to simulate the long-term behaviour of tuffs and clarify the positive versus adverse effects of consolidation.

Acknowledgments The authors gratefully acknowledge the funding by the DAAD-MÖB. The support received from the Hungarian Science Fund (OTKA, K 63399, Á. Török, L. Z. Forgó) is also appreciated. We would like to acknowledge by Georg Hilbert, Peter Koblischek, Eberhard Wendler and Heinz Geich for their help with the conserving agents. Michael Auras is thanked for constructive and detailed review.

Open Access This article is distributed under the terms of the Creative Commons Attribution Noncommercial License which permits any noncommercial use, distribution, and reproduction in any medium, provided the original author(s) and source are credited.

\section{References}

Alvarez de Buergo M, Fort R (2002) Characterizing the construction materials of a historic building and evaluating possible preservation treatments for restoration purposes. In: Siegesmund S, Weiss TS, Vollbrecht A (eds) Natural stones, weathering phenomena, conservation strategies and case studies, vol 205. Geological Society, London, Special Publications, pp 241-254

Auras M (2000) Entwicklungen in der Steinkonservierung 19902000. In: 10 Jahre Institut für Steinkonservierung e.V. Mainz, IFS Bericht 10:17-34

Auras M, Steindlberger E (2005) Verwitterung und Festigung vulkanischer Tuffe. Zeitschrift der Deutschen Gesellschaft für Geowissenschaften 156(1):167-175

Auras M, Egloffstein P, Steindlberger E (2000) Vulkanische Tuffsteine-Entstehung, Verwitterung, Konservierung. IFS-Bericht, Mainz 10:35-52

Boos M (2004) Korn für Korn: Natursteinkonservierung und Steinfestiger. Der Maler und Lackierermeister 3:14-18

Boos M, Grobe J, Hilbert G, Muller-Rochholz J (1996) Modified elastic silicic-acid ester applied on natural stone and tests of their efficiency. In: Riederer J (ed) Proceedings of the 8th international congress on deterioration and conservation of stone. Möller, Berlin 2:1179-1185

Egloffstein P (1998) Vulkanische Tuffsteine als Werksteine an historischen Bauwerken in Ungarn und Deutschland. $\mathrm{PhD}$ thesis, Sven von Loga, Köln, 154 p

Egloffstein P, Kertész P, Althaus E (1996) Vulkanische Tuffe als Werksteine: Zerfallprozesse und Konservierungsmöglichkeiten. In: Erhalten historisch bedeutsamer Bauwerke. Ernst, Sohn, Berlin, pp 183-190

Ettl H, Pfanner M, Clauß H (2006) Das Kindergrabmal La Roche in Basel. Konservierung und Restaurierung von Carrara-Marmor. Restauro 112/3:174-181

Fitzner B (1994) Volcanic tuffs: the description and quantitative recording of their weathered state. In: Charola AE, Koestler RJ, Lombardi $G$ (ed) Proceedings of the international meeting "Lavas and volcanic tuffs", Easter Island, Chile, 25-31 October 1990, pp 33-51. ICCROM 1994

Fitzner B, Basten D (1994) Gesteinporosität-Klassifizierung, messtechnische Erfassung und Bewertung ihrer Verwitterungsrelevanz. In: Snethlage $\mathrm{R}$ (ed) Jahresberichte SteinzerfallSteinkonservierung 1992. Ernst \& Sohn, Berlin, pp 19-32 
Fassina V, Pezzeta E, Cherido M, Naccari A, Melica D (2004) A survey on the behaviour of restoration materials of the Loggia Cornaro in Padova, after fifteen years. In: Kwiatkowski D, Löfvendahl R (eds) 10th International congress on deterioration and conservation of stone, Stockholm

Forgó L, Stück H, Maróthy, Siegesmund S, Török Á, Ruedrich J (2006) Materialverhalten von natürlichen und modellhaft konsolidierten Tuffen. IFS-Bericht, Koblenz 22:65-75

Furlan V, Félix C (2000) La pierre du portail peint de la cathédrale de Lausanne: nature, état de conservation et consolidation. In: Fassina V (ed) 9th International congress on deterioration and conservation of stone, Venice. Elsevier, Amsterdam, pp 633-640

Grassegger G. (2002) Restoration of the sarcophagus of duke Melchior von Hatzfeld-the accompanying scientific and technical investigations. Otto Graf J 13:141-154

Grimm WD (2005) Untersuchungen am Denkmalbestand deutscher Friedhöfe-Gesteine, Verwitterungserscheinungen, Restaurierungen. In: Siegesmund S, Auras M, Snethlage R (eds) SteinZerfall und Konservierung. Institut für Steinkonservierung e.V., Leipzig, pp 61-69

Grobe J, Boos M, Wolke A, Zeine Ch (2001) Schutz von Steinoberflächen durch Applikation elastischer KieselsäureEster-Bilanz eines DBU-Projekts. NatursteinkonservierungGrundlagen, Entwicklungen und Anwendungen. WTA Schriftenreihe, Aedifikatio, Freiburg 23:9-32

Hilbert G (1999) Natursteinkonservierung: Mittel und Durchführung. Naturstein 2:44-49. ISSN: 0028-1026

Ibach HW, Ibach K (2005) Grenzen und Möglichkeiten der Vollkonservierung von Naturwerksteinen. In: Siegesmund S, Auras M, Snethlage R (eds) Stein-Zerfall und Konservierung. Institut für Steinkonservierung e.V., Leipzig, pp 122-125

Lazzarini L, Lombardi G, Marconi F, Meucci C (1996) New data on the characterisation and conservation of the Easter Island's pyroclastics used for the Moais. In: Riederer J (ed) Proceedings of the 8th international congress on deterioration and conservation of stone. Möller, Berlin 2:1147-1157

Leisen H, von Plehwe-Leisen E (2005) Der Tempel von Angkor Wat in Kambodscha-Erfahrungen mit Steinersatzmassen im Kieselsäureester-Modulsystem. Zeitschrift der Deutschen Geologischen Gesellschaft 156(1):231-238

Lorenz HG, Ibach HW (1999) Marmorkonservierung durch die IbachVolltränkung: Qualitätskontrolle und Optimierung durch mikroskopische und petrophysikalische Untersuchungen. Zeitschrift der Deutschen Geologischen Gesellschaft 150:397-406

Pfefferkorn S, Siedel H (2001): Einfluss der Materialfeuchte auf die Ergebnisse des Bohrwiderstand-Messverfahrens an Sandsteinen verschiedener Gefügetypen-5

Price CA (1996) Stone conservation, an overview of current research. The Getty Conservation Institute, Los Angeles, 73 p
Ruedrich J, Kirchner D, Seidel M, Siegesmund S (2005) Beanspruchungen von Naturwerksteinen durch Salz- und Eiskristallisation im Porenraum sowie hygrische Dehnungsvorgänge. Zeitschrift der Deutschen Geologischen Gesellschaft 156(1):59-73

Snethlage R (1984) Steinkonservierung. Bayerische Landesamt für Denkmalpflege, Arbeitshefte 22, München, 203 p

Snethlage R (1997) Leitfaden Steinkonservierung. Fraunhofer IRB Verlag, Stuttgart

Snethlage R (2005) Leitfaden Steinkonservierung: Planung von Untersuchungen und Maßnahmen zur Erhaltung von Denkmälern aus Naturstein. Fraunhofer IRB Verlag, Stuttgart, 288 p

Steindlberger E (2002) Untersuchungen zum physiko-chemischen Verwitterungsverhalten hessischer Tuffsteine. Frankfurter Geowissenschaftliche Arbeiten, Frankfurt am Main, 20, 67 p

Steindlberger E (2004) Volcanic tuff from hesse (Germany) and their weathering behaviour. Special issue: stone decay hazzards. Environ Geol 46:378-390

Strohmeyer D (2003) Gefügeabhängigkeit technischer Gesteinseigenschaften. PhD thesis, University of Göttingen, Göttingen, $254 \mathrm{p}$

Török Á, Gálos M, Kocsányi-Kopecskó K (2004) Experimental weathering of rhyolite tuff building stones and effect of an organic polymer conserving agent. In: Smith BJ, Turkington AV (eds) Stone decay, its causes and controls. Donhead, Dorset, pp 109-127

Török Á, Vogt T, Löbens S, Forgó LZ, Siegesmund S, Weiss T (2005) Weathering forms of rhyolite tuffs. Zeischrift der Deutschen Gesellschaft für Geowissenschaften 156:1, Stuttgart, 177-187

Török Á, Forgó LZ, Vogt T, Löbens S, Siegesmund S, Weiss T (2007) The influence of lithology and pore-size distribution on the durability of acid volcanic tuffs. In: Přikryl R, Smith BJ (eds) Building stone decay: from diagnosis to conservation. Geological Society, London, Special Publications, 271:251-260

Utz R (2004) Stabilisierung von Lösslehmoberflächen in archäologischen Grabungen am Beispiel der Terrakottaarmee des Qin Shihuangdi. PhD thesis, Ludwig Maximilian University, München, $212 \mathrm{p}$

von Plehwe-Leisen E, Scheuren E, Schumacher T, Wolff A (2004) Steine für den Kölner Dom. Kölner Dom, Köln, 100 p

Weber H (1983) Steinkonservierung: der Leitfaden zur Konservierung und Restaurierung von Natursteinen. Expert, Grafenau, 197 p

Weber H (1993) Qualität ist kein Zufallsprodukt—Die Gedächtniskirche zehn Jahre nach der Sanierung. Bausubstanz 1:1-8

Wendler E (2001) Elastifizierte Kieselsäureester als mineralische Bindemittel für unterschiedliche Konservierungsziele. Praktische Erfahrungen mit dem KSE-Modulsystem. Natursteinkonservierung: Grundlagen, Entwicklungen und Anwendungen. WTASchriftenreihe, Aedificatio, Freiburg, 23:55-78 